\title{
Comparison of Visual and Instrumental Assessment of Colour Differences on Finished Wooden Surfaces
}

\section{Usporedba vizualne procjene i izmjerene promjene boje površinski obrađenog drva}

\author{
Preliminary paper • Prethodno priopćenje \\ Received-prispjelo: 20. 10. 2019. \\ Accepted-prihvaćeno: 28. 4. 2020. \\ UDK: $630 * 829$ \\ https://doi.org/10.5552/drvind.2020.1954
}

\begin{abstract}
Staining of wood with various substances and processes is an important part of surface finishing of wood. Colour differences as a result of staining and of exposure of coloured wood during its utilisation are usually evaluated by instrumental measurements. However, the measurement results can show something else compared to what our naked eye can see. Due to inhomogeneity of wood, this discrepancy can be even greater in the case of finished surfaces. The aim of our research was to evaluate distinctions between visual perception and numerically determined colour differences on differently finished wooden surfaces, to get information at which starting point the colour difference becomes visible, and to establish whether it is related to the nature of the surface. We established that the visual assessment is influenced by many factors and that there is a correlation between visual and instrumental assessments. The colour difference $\Delta E^{*}$ of 0.5 should be considered as a value when it starts to become visible, and at the value of 2.0, observers already considered the colour difference as a different colour. It was stated that we have some tolerance in perceiving the colour change. This tolerance is more expressed in the case of transparent coating systems.
\end{abstract}

Keywords: coating; colour; gloss; instrumental measurement; visual perception

SAŽETAK • Premazivanje drva različitim sredstvima i primjenom različitih postupaka važan su dio površinske obrade drva. Promjene boje kao rezultat premazivanja i izlaganja obojenog drva tijekom njegove uporabe obično se mjere uređajima. Međutim, izmjereni rezultati pokazuju nešto sasvim drugo od onoga što se vidi ljudskim okom. Kad je riječ o površinskoj obradi drva, razlike između izmjerenih rezultata i onoga što se vidi ljudskim okom mogu se povećati zbog nehomogenosti drva. Cilj istraživanja bio je procijeniti razlike između vizualne procjene i izmjerene promjene boje na površinski obrađenom drvu primjenom različitih tehnika kako bi se utvrdila vrijednost pri kojoj je promjena boje vidljiva te kako bi se utvrdilo ovisi li ona o vrsti površine. Ustanovili smo da na vizualnu procjenu promjene boje utječe velik broj čimbenika i da postoji veza između vizualne procjene i izmjerenih vrijednosti promjene boje. Promjena boje $\Delta E^{*}$ od 0,5 vrijednost je pri kojoj promjena boje postaje vidljiva, a promjenu boje od 2 promatrači vide kao različitu boju. Uočeno je da postoji određena tolerancija u percepciji promjene boje, koja je veća pri procjeni promjene boje prozirnih sustava premaza.

Ključne riječi: premaz; boja; sjaj; mjerenje promjene boje; vizualna procjena

\footnotetext{
${ }^{1}$ Authors are teaching assistant and full professor at University of Ljubljana, Biotechnical Faculty, Department of Wood Science and Technology, Ljubljana, Slovenia.
} 


\section{INTRODUCTION}

\section{UVOD}

Wood as a natural material has many advantages compared to other materials. Among them, visual properties are most often the reason for selecting wood for a desired product. There are huge differences in the appearance of wood between different tree species and even among wood of the same species. The decorative appearance of timbers is due to the texture, or to the figure, or to the colour of the material and, in many instances, due to combinations of these (Dinwoodie, 2000). Such variability in wood appearance gives endless possibilities for its use. However, at the same time and for the same reason, this could also be a disadvantage that needs to be overcome. Sometimes it is hard to achieve the same appearance between different surfaces or different pieces of a wooden product, especially if it is not produced in a small series. Furthermore, wood surfaces of furniture or some other product are coated for protection or to give them the final look. The appearance of the finished wooden surfaces than depends on the wood used as a substrate, on the materials applied on it and on various other parameters, such as, for instance, an application rate.

In spite of the fact that colour variations are quite frequent and expected in the case of wooden furniture or other wooden products, customers do have certain tolerance limits above which the colour differences are no longer tolerated. Colour vision is an illusion created by the interactions of billions of neurons in our brain. There is no colour in the external world; it is created by neural programs and projected onto the outer world we see. It is intimately linked to the perception of form, where colour facilitates detecting the borders of objects (Gouras, 2013). From this, we can conclude that colour vision and perception of colour differences are unique to every individual. This suggests that colour evaluation can only be objective by the use of equipment that numerically measures the colour according to a certain colour space system. The most commonly used system for measuring the colour, including the one of wood, is CIELAB colour space (Golob and Golob, 2000). There are many studies on using this colour system for the evaluation of colour stability of coated or non-coated wood due to natural or artificial weathering (Vardanyan et al., 2015), and even more, for the determination of wood colour changes after various treatments (modification or drying) (Nemeth et al., 2013; Sikora et al., 2018) or due to fungal attack (Reinprecht and Hulla, 2015).

However, up to our best knowledge, there are only few reports on the relation between visual and instrumental assessment of the colour of wood, as described in the next paragraph (Liu and Furuno, 2002; Buchelt and Wagenführ, 2012; Defoirdt et al., 2012; Hauptman et al., 2012; Bianconi et al., 2013), and there are some more reports about this topic with applications on other materials. For instance, the correlation of perceived colour difference and the measured and mathematically calculated difference with the focus on print- ing industry was elaborated by Mokrzycki and Tatol (2011). The correlation of the instrumental colour differences with visual assessment is extremely important in automotive coatings (Kirchner and Ravi, 2014; Gómez et al., 2016), in dental medicine (Pecho et al., 2016; Pecho et al., 2016a), in food industry (Pagliarini and Rastelli, 1994; O'Sullivan et al., 2003), in textile industry (Bae et al., 2015), in the production of colour tints (Khimchenko and Eksperiandova, 2014), etc.

There have been only few investigations in the field of wood science and technology dealing with the relation of visual and instrumental assessment of colour. Liu and Furuno (2002) characterised colour variations of the surfaces of fifteen wood species by fractal dimension of the triangular prism surface area method. They came to the conclusion that, for colour matching of wood parts, fractal dimension quantitatively furnishes essential information of colour variation in local and overall features. Buchelt and Wagenführ (2012) measured the natural colour of six precious woods. They established that, within one wood species with equal surfaces, there are colour differences $\left(\Delta E^{*}\right)$ with a magnitude of 1 to 2 and concluded that the grading of $\Delta E^{*}$ as a difference that is barely perceptible should be higher than 2 . They came to this conclusion by the comparison of established colour differences within one species and colour difference values obtained by visual evaluation performed by Bieske (acc. to Buchelt and Wagenfür (2012)). Defoirdt et al. (2012) assessed the colour of oak wood for the production of parquet. They compared visual assessment and spectrophotometer measurements and established that their colour grading methodology is in good correlation with visual assessment and therefore can be adapted to particular automated grading purposes. Bianconi et al. (2013) also analysed coloured-based sorting through different colour descriptors of hardwood parquet slabs into lots of similar visual appearance, but they did not do any comparison to visual assessment. Hauptman and coauthors (2012) correlated the visual perception of the oak wood colour of 20 observers with two different colour difference equations, CIELAB from DIN 6174:200712 and CIEDE2000 (CIE, 2001) equation. They established that CIELAB equation showed generally an overestimation of the colour change $\left(\Delta E^{*}\right)$.

Taking into account relatively low number of investigations of the relationship between visual perception of colour and colour difference and instrumental assessment of colour in the case of wood, the aim of our research was to additionally elucidate this question. The aim was also to get information at which starting point the colour difference in terms of the CIELAB $\Delta E^{*}$ value becomes visible and to establish whether this is somehow related to the nature of the finished wooden surface. The colour is a psychophysical quantity, acting as an impression during the stimulation of our visual system (Mokrzycki and Tatol, 2011). The dependence on many external factors and individual human characteristics has a significant influence on the perception and comparison of colour experiences (Mokrzycki and Tatol, 2011). We are aware that 
the perception of colour differences is influenced by many factors and that the effect of each individual factor could be quantified, but such a study would be by far above our intentions to just additionally elucidate this issue in the field of wood surface finishing. Further on, it is also accepted that the effect of texture on colour appearance is important (Kirchner and Ravi, 2014; Bae et al., 2015), but again, it was decided that using the texture model would exceed the purpose of this investigation.

\section{MATERIALS AND METHODS 2. MATERIJALI I METODE}

For the assessment of colour differences, we used 12 pairs of differently finished wooden surfaces. The pairs of surfaces differed by the type of substrate (type of wood or composite), the intention of the use of surface (interior / exterior), the coating system properties (colour, hiding power, build, gloss) and the texture of the surface. The pairs of samples, intended for the interior, were prepared in a way that one sample was cut to two smaller, equally large specimens. The pairs of samples for the exterior were not prepared by cutting one specimen into two pieces, as in the case of the samples for the interior. Instead, in the pairs of samples for the exterior, there were two pieces of the same substrate, each treated with a surface finish of a different manufacturer, but of a very similar colour and gloss.

One sample of each comparative pair was stored in a dark space in which there were constant climatic conditions with the temperature of $(23 \pm 2){ }^{\circ} \mathrm{C}$ and relative air humidity of $(50 \pm 5) \%$, while the second sample was irradiated with UV light (Osram ULTRA VITALUX $300 \mathrm{~W}$ ) to increase the colour differences between samples in a single pair, for 1, 6 and 8 days or until most of the observers detected more than the obvious colour differences between the comparable samples in the pair. This was considered as a different colour. However, the purpose of UV irradiation was not to study its effects on colour or colour change. It was used just as a tool for changing the colour difference between comparative pairs of samples. The colour was measured and colour differences were calculated before each visual assessment. The values were not known to the observers.

\subsection{Gloss measurements}

\subsection{Mjerenje sjaja}

To additionally describe the observed surface systems and to see any possible effects of gloss on visual perception of the colour, we measured specular gloss (X-Rite AcuGloss TRI) by the method described in EN ISO 2813 (2015), and did a classification based on specular reflectance values when tested at $60^{\circ}$ by the following categories according to EN 927-1 (2013):

a) matt: reflectance up to 10 ,

b) satin: reflectance greater than 10 and up to 35 ,

c) semi gloss: reflectance greater than 35 and up to 60 ,

d) gloss: reflectance greater than 60 and up to 80 ,

e) high gloss: reflectance greater than 80 .

\subsection{Colour measurements}

\subsection{Mjerenje boje}

The surface colour difference of samples in a pair was evaluated based on the CIELAB colour coordinates (EN ISO 11664-4:2011). A colour measuring instrument (spectrophotometer X-Rite SP 62) was used to record the colour index with diffuse $/ 8^{\circ}$ sphere optical geometry, fixed $14 \mathrm{~mm}$ aperture, specular component included, illuminant D65 and a $10^{\circ}$ standard observer. The colour parameters of each surface were measured at ten positions and the mean value was recorded. The total colour difference $\left(\Delta E^{*}\right)$ was used to assess the colour difference between the samples in the pair and was calculated as follows:

$$
\begin{gathered}
\Delta L^{*}=\Delta L^{*}{ }_{1}-\Delta L_{0}^{*} \\
\Delta a^{*}=\Delta a^{*}{ }_{1}-\Delta a^{*}{ }_{0} \\
\Delta b^{*}=\Delta b^{*}{ }_{1}-\Delta b^{*}{ }_{0} \\
\Delta E^{*}=\left(\Delta L^{* 2}+\Delta a^{* 2}+\Delta b^{* 2}\right)^{1 / 2}
\end{gathered}
$$

where $\Delta E^{*}$ represents the total colour difference, $L^{*}$ is the lightness and darkness of colour, $a^{*}$ is the redness and greenness of colour, $b^{*}$ is the yellowness and blueness of colour, and $\Delta L^{*}, \Delta a^{*}$, and $\Delta b^{*}$ are the differences of the compared (1) and reference sample kept in the dark (0) of $L^{*}, a^{*}$, and $b^{*}$, respectively.

\subsection{Visual assessment of colour differences}

2.3. Vizualna procjena promjene boje

Visual assessment of colour differences was done by comparison of 12 pairs under the same light (indoor light, combination of daylight at sunny conditions at 13.00 and laboratory Philips fluorescent light bulbs TL-D $36 \mathrm{~W}$ with cool white colour designation and temperature of $4100 \mathrm{~K}$ ) and background conditions, made by 24 students of Wood Science (University of Ljubljana, Biotechnical Faculty), all male and from 22 to 23 years. The perceived colour differences were not statistically evaluated, like for instance by Bae and coauthors (2015). This was decided because of the relatively low number of observers and especially because the structure of the group of observers did not reflect the structure of general population in terms of age and gender. For each assessment, the observers were asked to mark on the survey sheet if they see the colour difference between the comparative samples or not (None). Furthermore, if their answer was yes, than they were asked to state if in their opinion this colour change could still be inside tolerance limits (Acceptable) or not (Not acceptable), or if they considered the assessed colour difference more than obvious so that the comparative samples could not in any case be considered as the samples of the same colour (Different colour).

\section{RESULTS AND DISCUSSION}

\section{REZULTATI I RASPRAVA}

All results of visual and instrumental assessments of colour differences on 12 pairs of different fin- 
ished wooden surfaces are presented in Table 1. Instrumentally determined differences between paired samples are presented as total colour difference values $\Delta E^{*}$ and differences of each individual colour coordinate $\left(\Delta L^{*}, \Delta a^{*}\right.$ and $\left.\Delta b^{*}\right)$. Visual assessment of colour differences is presented with the level of acceptance for each grade separately. The grade with the highest percent of selection from 24 evaluators among all grades is marked with a grey cell.

In the case of the first pair (1), we can see that despite a rather high colour difference measured at the end of the comparison $\left(\Delta E^{*}=0.83\right)$, the majority of the observers $(81.8 \%)$ did not see the difference between these two compared samples. However, it is interesting that in case of the similar pair 2 (same finish but different substrate), the observers saw the difference already at quite low measured colour difference $\left(\Delta E^{*}=0.54\right)$. The samples of the first pair (pair 1) were finished with "open pores" due to large vessels of mahogany wood, while the surfaces of the finished samples with spruce wood as a substrate (pair 2) were smooth. From this, we can conclude that surface roughness can blur our ability to detect colour differences. Of course, we must also have in mind that different colour of the substrate underneath the semi-transparent coating film somehow also contributes to different colour of the whole surface system and induces a colour change. It is also interesting that the observers, in the case of another similar pair, pair 3 (same substrate, but different, opaque stain), saw the colour difference $(80.9 \%)$, evaluated as not acceptable, already at the measured value of $\Delta E^{*}=$ 0.56 . It seems that visibility of the substrate somehow softens our criteria for visual assessment. The tolerance of the observer's vision for the colour difference was even higher in the case of systems without the coating film. The colour difference between black walnut wood samples treated with linseed oil (pair 11) was considered as high (different colour) at a measured $\Delta E^{*}$ value of 7.98 and in the case of untreated spruce samples (pair 12, ) at the measured $\Delta E^{*}$ value of 12.60 . If the substrate is coated with a transparent coating system, then the situation is reversed (pairs 5, 6 and 7). In the case of pair 5 , the observers saw the colour difference that was not acceptable at the measured $\Delta E^{*}$ value of 1.17 , while in the systems also with transparent coatings but stained substrate such perception occurred at much higher values (pair $6-\Delta E^{*}=2.95$; pair $7-$ $\Delta E^{*}=3.16$ ). Pair 9 was the only high gloss opaque surface system. The observers mostly did not see the colour difference even in the case of the highest measured $\Delta E^{*}$ value of 0.41 . However, these results show a trend which indicates that this perception could easily happen at $\Delta E^{*}$ value around 0.5 , which for example is the maximum value of the colour difference according to IKEA specification (Tokarski and Nussbaum, 2014). Regarding the pair of samples with the satin decorative foil (pair 10), even in the case of the highest measured $\Delta E^{*}$ values of 2.28 or 2.80 , the observers considered them as the samples with a similar colour with acceptable colour difference (with $63.6 \%$ and $54.5 \%$ of agreement). This pair was the only pair with a decora- tive foil and, maybe in the case of foils, the observers are subconsciously more tolerant since they consider such surfaces as low cost ones.

The results showed (Table 1) that the observers were very susceptible to detecting the colour differences. The minimum value of the measured colour difference at which most observers detected the colour difference was quite low $\left(\Delta E^{*}=0.45\right.$; pair 8$)$, but it is interesting that the value at which the observers considered the colour difference as no longer acceptable was quite close to this one $\left(\Delta E^{*}=0.58\right.$; pair 3$)$. The minimum value of the measured colour difference at which the observers considered the samples to have a different colour was 2.03 (pair 4). All these values (acceptable and not acceptable colour differences) are quite lower than the ones reported by Buchelt and Wagenfür (2012), who established that the grading $\Delta E^{*}=$ 2 is barely perceptible for visual perception of colour of precious woods (non-treated ones). However, they are closer to the values of evaluation of colour differences $\left(\Delta E^{*}\right)$ obtained by Bieske (cited in Buchelt and Wagenfür, 2012):

- up to 0.5 : no to nearly no colour difference

- $0.5-1.0$ : difference can be perceptible for the practiced eye

$-1.0-2.0$ : observable colour difference that is barely seen

$-2.0-4.0$ : perceived colour difference that is certainly seen

- 4.0 - 5.0: significant colour difference that is seldom accepted

- above 5.0: the difference is evaluated as another colour

Bieske has worked out a valuation of the perception of light and body colours, where differences of light and body colours were evaluated by a number of subjects of different age groups.

Gómez et al. (2016) also examined the correlation between visual and instrumental assessment of colour differences in automotive coatings determined by the colour difference formula AUDI2000 (specific for this sector) (Pecho et al., 2016). They revealed that an acceptable correlation exists. Hauptman and co-authors (2012) and Pecho and co-authors (2016a) used CIELAB and CIEDE2000 colour difference formulas for colour and colour differences. They both concluded that CIELAB is not the best metrics to calculate colour differences and that CIEDE2000 equation is generally better in predicting colour differences. In our investigation, we did not use the CIEDE2000 (EN ISO 116646, 2016) or AUDI2000 formula (Gómez et al., 2016), but nevertheless we also found a good correlation between CIELAB colour difference formula and visual perception. Generally, if the measured colour difference $\left(\Delta E^{*}\right)$ increased or decreased, the ability of visual perception of colour difference changed in the same way. The only significant exception was in case of pair 1 , where the measured colour difference $\left(\Delta E^{*}\right)$ increased due to UV irradiation but the observers saw less colour difference between these two paired samples. We cannot explain why this happened. Even if we 
Table 1 Instrumentally $\left(\Delta E^{*}, \Delta L^{*}, \Delta a^{*}\right.$ and $\left.\Delta b^{*}\right)$ and visually determined colour differences (the level of acceptance for the grades: none, accepted, not accepted and different colour)

Tablica 1. Izmjerena $\left(\Delta E^{*}, \Delta L^{*}, \Delta a^{*} \mathrm{i} \Delta b^{*}\right)$ i vizualno utvrđena razlika u boji (ocjene stupnja prihvaćanja: nema, prihvatljivo, nije prihvatljivo i različita boja)

\begin{tabular}{|c|c|c|c|c|c|c|c|c|c|c|c|}
\hline \multirow[b]{2}{*}{$\begin{array}{l}\text { Pair } \\
\text { Par }\end{array}$} & \multicolumn{2}{|c|}{$\begin{array}{l}\text { Surface system } \\
\text { Površinski sustav }\end{array}$} & \multirow[b]{2}{*}{$\begin{array}{l}\mathbf{U V} \mathbf{V}^{2} \\
\text { (days) } \\
U V^{2} \\
(\text { dani })\end{array}$} & \multirow[b]{2}{*}{$\Delta \boldsymbol{E}^{*}$} & \multirow[b]{2}{*}{$\Delta \boldsymbol{L}^{*}$} & \multirow[b]{2}{*}{$\Delta a^{*}$} & \multirow[b]{2}{*}{$\Delta b^{*}$} & \multicolumn{4}{|c|}{$\begin{array}{l}\text { Visible colour difference } \\
\text { Vidljiva promjena boje }\end{array}$} \\
\hline & $\begin{array}{l}\text { Substrate } \\
\text { Podloga }\end{array}$ & $\begin{array}{l}\text { Finishing (gloss values in } \\
\text { g.u. in parentheses) } \\
\text { Premaz (u zagradama su }^{1} \\
\text { vrijednosti sjaja, JS) }^{l}\end{array}$ & & & & & & $\begin{array}{l}\text { None } \\
\text { Nema }\end{array}$ & $\begin{array}{l}\text { Acc. } \\
\text { Prih- } \\
\text { vatljivo }\end{array}$ & \begin{tabular}{|c|} 
Not \\
acc. \\
Nije \\
prih- \\
vatliivo
\end{tabular} & $\begin{array}{c}\text { Diff. } \\
\text { colour } \\
\text { Razli- } \\
\text { čita } \\
\text { boja }\end{array}$ \\
\hline \multirow{4}{*}{1} & \multirow{4}{*}{$\begin{array}{l}\text { Mahogany wood } \\
\text { drvo mahagonija }\end{array}$} & \multirow{4}{*}{$\begin{array}{l}\text { Satin }(12.1) \text { semi-transparent } \\
\text { brown exterior stain } \\
\text { poluprozirna smeđa lazura za } \\
\text { eksterijer }(12,1)\end{array}$} & 0 & 0.33 & -0.03 & -0.18 & 0.27 & $61.9 \%$ & $38.1 \%$ & $0.0 \%$ & $0.0 \%$ \\
\hline & & & 1 & 0.42 & -0.06 & \begin{tabular}{|l|}
-0.41 \\
\end{tabular} & -0.06 & $86.4 \%$ & $13.6 \%$ & $0.0 \%$ & $0.0 \%$ \\
\hline & & & 6 & 0.67 & -0.29 & -0.55 & -0.26 & $63.6 \%$ & $36.4 \%$ & $0.0 \%$ & $0.0 \%$ \\
\hline & & & 8 & 0.83 & -0.30 & -0.66 & -0.41 & $81.8 \%$ & $18.2 \%$ & $0.0 \%$ & $0.0 \%$ \\
\hline \multirow{4}{*}{2} & \multirow{4}{*}{$\begin{array}{l}\text { Spruce wood } \\
\text { drvo smreke }\end{array}$} & \multirow{4}{*}{$\begin{array}{l}\text { Satin }(15.8) \text { semi-transparent } \\
\text { brown exterior stain } \\
\text { poluprozirna smeđa lazura za } \\
\text { eksterijer }(15,8)\end{array}$} & 0 & 0.63 & 0.343 & 0.34 & 0.40 & $4.8 \%$ & $23.8 \%$ & $66.6 \%$ & $4.8 \%$ \\
\hline & & & 1 & 0.54 & 0.15 & 0.29 & 0.43 & $40.9 \%$ & $40.9 \%$ & $13.7 \%$ & $4.5 \%$ \\
\hline & & & 6 & 0.43 & 0.09 & 0.29 & 0.30 & $54.5 \%$ & $45.5 \%$ & $0.0 \%$ & $0.0 \%$ \\
\hline & & & 8 & 0.42 & 0.08 & 0.35 & 0.21 & $50.0 \%$ & $36.4 \%$ & $13.6 \%$ & $0.0 \%$ \\
\hline \multirow{4}{*}{3} & \multirow{4}{*}{$\begin{array}{l}\text { Mahogany wood } \\
\text { drvo mahagonija }\end{array}$} & \multirow{4}{*}{$\begin{array}{l}\text { Satin (15.7) opaque dark } \\
\text { green exterior stain / pokrivna } \\
\text { tamnozelena lazura za } \\
\text { eksterijer }(15,7)\end{array}$} & 0 & 0.56 & -0.19 & 0.14 & 0.51 & $4.8 \%$ & & $80.9 \%$ & $4.8 \%$ \\
\hline & & & 1 & 0.58 & 0.03 & 0.14 & 0.56 & $0.0 \%$ & $45.5 \%$ & $54.5 \%$ & $0.0 \%$ \\
\hline & & & 6 & 0.62 & 0.12 & 0.12 & 0.59 & $4.5 \%$ & & $50.0 \%$ & $4.5 \%$ \\
\hline & & & 8 & 0.65 & 0.06 & 0.06 & 0.64 & $9.1 \%$ & & $50.0 \%$ & $13.6 \%$ \\
\hline 4 & $\begin{array}{l}\text { Spruce wood } \\
\text { drvo smreke }\end{array}$ & $\begin{array}{l}\text { Satin (27.7) opaque dark } \\
\text { green exterior stain / pokrivna } \\
\text { tamnozelena lazura za } \\
\text { eksterijer }(27,7)\end{array}$ & 0 & 2.03 & 1.25 & 1.20 & -1.10 & $0.0 \%$ & $0.0 \%$ & $23.8 \%$ & $76.2 \%$ \\
\hline \multirow{3}{*}{5} & \multirow{3}{*}{$\begin{array}{l}\text { Fibreboard, fine line } \\
\text { veneer } \\
\text { ploča vlaknatica, } \\
\text { fine line furnir }\end{array}$} & \multirow{3}{*}{$\begin{array}{l}\text { Satin }(31.3) \text { transparent } \\
\text { coating } \\
\text { prozirni premaz }(31,3)\end{array}$} & 0 & & 0.10 & -0.45 & & & & $4.8 \%$ & $0.0 \%$ \\
\hline & & & 1 & 1.17 & -0.80 & \begin{tabular}{|l|}
-0.36 \\
\end{tabular} & \begin{tabular}{|l|}
0.77 \\
\end{tabular} & $0.0 \%$ & $9.1 \%$ & $63.6 \%$ & $27.3 \%$ \\
\hline & & & 6 & 2.22 & -0.28 & -0.34 & 2.18 & $0.0 \%$ & $4.5 \%$ & $40.9 \%$ & $54.5 \%$ \\
\hline \multirow[b]{2}{*}{6} & \multirow{2}{*}{$\begin{array}{l}\text { Fibreboard, fine line } \\
\text { veneer } \\
\text { ploča vlaknatica, } \\
\text { fine line furnir }\end{array}$} & \multirow{2}{*}{$\begin{array}{l}\text { Grey stain and satin (32.9) } \\
\text { transparent coating / sivo } \\
\text { močilo i prozirni premaz } \\
(32,9)\end{array}$} & 0 & 1.01 & & 0.30 & & & & $19.1 \%$ & $0.0 \%$ \\
\hline & & & 1 & 2.95 & -0.84 & 0.23 & 2.81 & $0.0 \%$ & $9.1 \%$ & $18.2 \%$ & $72.7 \%$ \\
\hline & Fibreboard, exotic & & 0 & & & 25 & & & & $0.0 \%$ & $0.0 \%$ \\
\hline 7 & wood veneer & (26.7) transparent coating / & 1 & 0.93 & 0.59 & 0.15 & 0.70 & $40.9 \%$ & $59.1 \%$ & $0.0 \%$ & $0.0 \%$ \\
\hline & $\begin{array}{l}\text { ploča vlaknatica, } \\
\text { furnir egzota }\end{array}$ & $\begin{array}{l}\text { smeđosivo močilo i prozirni } \\
\text { premaz }(26,7)\end{array}$ & 6 & 3.16 & 1.98 & -0.57 & 2.40 & $0.0 \%$ & $4.5 \%$ & $40.9 \%$ & $54.6 \%$ \\
\hline & & Dark brown stain & 0 & 0.61 & -0.35 & -0.25 & & $33.3 \%$ & $28.6 \%$ & $28.6 \%$ & $9.5 \%$ \\
\hline 8 & wood veneer & (13.9) transparent coating & 1 & 0.65 & -0.48 & -0.25 & -0.37 & $13.6 \%$ & $68.2 \%$ & $18.2 \%$ & $0.0 \%$ \\
\hline 8 & ploča vlaknatica, & tamnosmeđe močilo $i$ & 6 & 0.5 & -0.45 & -0.31 & -0.13 & $22.7 \%$ & & $9.1 \%$ & $4.5 \%$ \\
\hline & & transp & 8 & 0.45 & -0.36 & -0.23 & 0.12 & $18.2 \%$ & $68.2 \%$ & $9.1 \%$ & $4.5 \%$ \\
\hline & & High gloss (84.6) opaque & 0 & 0.18 & -0.04 & 0.00 & -0.18 & $95.2 \%$ & $4.8 \%$ & $0.0 \%$ & $0.0 \%$ \\
\hline 9 & Fibreboard & white coating & 1 & 0.10 & -0.10 & 0.00 & -0.03 & $90.9 \%$ & $9.1 \%$ & $0.0 \%$ & $0.0 \%$ \\
\hline 9 & & pokrivni bijeli premaz visokog & 6 & 0.34 & -0.19 & -0.06 & 0.28 & $100.0 \%$ & $0.0 \%$ & $0.0 \%$ & $0.0 \%$ \\
\hline & & & 8 & 0.41 & -0.18 & -0.07 & 0.36 & $59.1 \%$ & $40.9 \%$ & $0.0 \%$ & $0.0 \%$ \\
\hline & & & 0 & 1.38 & & -0.23 & & & & $4.7 \%$ & $0.0 \%$ \\
\hline 10 & Chipboard & Satin (16.3) decorative foil & 1 & 1.10 & -0.51 & -0.34 & -0.91 & $63.6 \%$ & $36.4 \%$ & $0.0 \%$ & $0.0 \%$ \\
\hline 10 & & & 6 & 2.28 & -1.50 & -0.59 & -1.62 & $18.2 \%$ & $63.6 \%$ & $9.1 \%$ & $9.1 \%$ \\
\hline & & & 8 & 2.80 & -1.90 & -0.74 & -1.91 & $9.1 \%$ & $54.5 \%$ & $27.3 \%$ & $9.1 \%$ \\
\hline & & Matt (4.9) & 0 & 3.36 & 1.34 & 0.37 & 3.06 & $4.5 \%$ & $40.9 \%$ & $36.4 \%$ & $9.1 \%$ \\
\hline 11 & & $\begin{array}{l}\text { linseed oil } \\
\text { laneno ulje }(4,9)\end{array}$ & 1 & 7.98 & 3.42 & 0.95 & 7.15 & $0.0 \%$ & $0.0 \%$ & $4.5 \%$ & $95.5 \%$ \\
\hline & & & 0 & 3.00 & -2.70 & 1.27 & 0.23 & $14.3 \%$ & $61.9 \%$ & $19.0 \%$ & $4.8 \%$ \\
\hline 12 & Spruce wood & $(6.3)$ & 1 & 5.27 & -4.75 & 1.12 & 1.97 & $0.0 \%$ & $40.9 \%$ & $36.4 \%$ & $9.1 \%$ \\
\hline & & & 6 & 12.60 & -7.52 & 2.74 & 9.73 & $0.0 \%$ & $0.0 \%$ & $9.1 \%$ & $90.9 \%$ \\
\hline
\end{tabular}

${ }^{1}$ Gloss values in parentheses were only measured prior exposure to UV light. In the case of pairs with exterior coatings of different producers, but very similar colour and gloss, the average values of both specimens in a pair are given. / Vrijednosti sjaja u zagradama izmjerene su prije izlaganja UV svjetlosti. Ako su premazi za eksterijer slične boje i sjaja bili različitih proizvođača, iskazana je srednja vrijednost sjaja obaju uzoraka u paru.

${ }^{2}$ The value 0 means that the assessment of colour difference was performed between both samples in the initially prepared pair that was not exposed to UV light. / Vrijednost 0 znači da je procjena razlike u boji bila provedena na oba uzorka u početno pripremljenom paru koji nije bio izložen UV svjetlosti. 
look at the change of every individual CIELAB colour parameter, we can see the same trend; after every UV irradiation, the exposed sample became darker $\left(-\Delta L^{*}\right)$, less reddish $\left(-\Delta a^{*}\right)$ and less yellowish $\left(-\Delta b^{*}\right)$.

\section{CONCLUSIONS 4. ZAKLJUČAK}

Visual assessment of colour differences is influenced by many factors. It is not only dependant on the real colour differences, as they can be determined by measurements, but also on the kind of the finished wooden surface system (the type of substrate and coating system, roughness and texture, etc.). Nevertheless, there is still a good correlation between visual and instrumental assessment of colour differences when using the CIELAB formula. For the finished wooden surfaces, the colour difference $\Delta \mathrm{E}^{*}$ of 0.5 should be considered as a value when the colour difference starts to be visible; in the case of dispute, it can be the matter of discussion till the value of 2.0 is reached, when the colour difference is already considered as a different colour. Our investigation also showed that we have some tolerance in perceiving the colour change. This tolerance is bigger if the coating system is more transparent so that the structure of the wood is more visible.

\section{Acknowledgements - Zahvala}

The authors would like to thank Boris Demšar for the experimental work, Borut Kričej for all of his help and to acknowledge the support of the Slovenian Research Agency within the research program P4-0015.

\section{REFERENCES}

5. LITERATURA

1. Bae, J. H.; Hong, K. H.; Lamar, T. M., 2015: Effect of texture on color variation in inkjet-printed woven textiles. Color Research and Application, 40 (3): 297-303. https://doi.org/10.1002/col.21865.

2. Bianconi, F.; Fernández, A.; González, E.; Saetta, S. A., 2013: Performance analysis of color descriptors for parquet sorting. Expert Systems with Applications, 40 (5): 1636-1644. https://doi.org/10.1016/j.eswa.2012.09.007.

3. Buchelt, B.; Wagenführ, A., 2012: Evaluation of color differences on wood surfaces. European Journal of Wood and Wood Products, 70 (1-3): 389-391. https://doi.org/10.1007/s00107-011-0545-z.

4. Defoirdt, N.; Wuijtens, I.; De Boever, L.; Coppens, H.; Van den Bulcke, J.; Van Acker, J., 2012: A color assessment methodology for oak wood. Annals of Forest Science, 69 (8): 939-946.

https://doi.org/10.1007/s13595-012-0214-3.

5. Dinwoodie, J. M., 2000: Timber: Its nature and behaviour. Second edition. E \& FN Spon, London, pp. 36.

6. Golob, V.; Golob, D., 2001: Teorija barvne metrike. In: Jeler, S., Kumar, M. (eds.), Interdisciplinarnost barve. Del 1. V znanosti. Društvo koloristov Slovenije, Maribor, pp. 201-230.

7. Gómez, O.; Perales, E.; Chorro, E.; Burgos, F. J.; Viqueira, V.; Vilaseca, M.; Martínez-Verdú, M.; Pujol, J., 2016: Visual and instrumental assessments of color differences in automotive coatings. Color Research and Application, 41 (4): 384-390. https://doi.org/10.1002/col.21964.
8. Gouras, P., 2013: “Color vision” (online), http://webvision.med.utah.edu/book/part-vii-color-vision/color-vision (Accessed March 10, 2018).

9. Hauptmann, M.; Pleschberger, H.; Mai, C.; Follrich, J.; Hansmann, C., 2012: The potential of color measurements with the CIEDE2000 equation in wood science. European Journal of Wood and Wood Products, 70 (4): 415-420. https://doi.org/10.1007/s00107-011-0575-6.

10. Khimchenko, S. V..; Eksperiandova, L. P., 2014: Colorimetric and stochastic assessment of the visual limit of color perception for visual colorimetric analysis. Journal of Analytical Chemistry, 69 (4): 322-326. https://doi.org/10.1134/S1061934814040042.

11. Kirchner, E. J. J.; Ravi, J., 2014: Setting tolerances on color and texture in automotive coatings. Color Research and Application, 39 (1): 88-96. https://doi.org/10.1002/col.21767.

12. Liu, J.; Furuno, T., 2002: The fractal estimation of wood color variation by the triangular prism surface area method. Wood Science and Technology, 36 (5): 385-397. https://doi.org/10.1007/S00226-002-0148-2.

13. Mokrzycki, W.; Tatol, M., 2011: Color difference Delta E - A survey. Machine Graphics and Vision, 20 (4): 383411.

14. Nemeth, R.; Ott, A.; Takats, P.; Bak, M., 2013: The Effect of Moisture Content and Drying Temperature on the Color of Two Poplars and Robinia Wood. BioResources, 8 (2): 2074-2083.

15. O’Sullivan, M. G.; Byrne, D. V.; Martens, H.; Gidskehaug, L. H.; Andersen, H. J.; Martens, M., 2003: Evaluation of pork colour: prediction of visual sensory quality of meat from instrumental and computer vision methods of colour analysis. Meat Science, 65 (2): 903-918. https://doi.org/10.1016/S0309-1740(02)00298-X.

16. Pagliarini, E.; Rastelli, J., 1994: Sensory and instrumental assessment of olive oil appearance. Grasas y Aceites, 45 (1-2): 62-64. https://doi.org/10.3989/gya.1994.v45.i1-2.972.

17. Pecho, O. E.; Ghinea, R.; Alessandretti, R., Pérez, M. M.; Della Bona, A., 2016a: Visual and instrumental shade matching using CIELAB and CIEDE2000 color difference formulas. Dental Materials, 32 (1): 82-92. https://doi.org/10.1016/j.dental.2015.10.015.

18. Pecho, O. E.; Pérez, M. M.; Ghinea, R.; Della Bona, A., 2016b: Lightness, chroma and hue differences on visual shade matching. Dental Materials, 32 (11): 1362-1373. https://doi.org/10.1016/j.dental.2016.08.218.

19. Reinprecht, L.; Hulla, M., 2015: Color changes in beech wood modified with essential oils due to fungal and ageing-fungal attacks with Coniophora Puteana. Drewno, 58 (194): 37-48.

20. Sikora, A.; Kačík, F.; Gaff, M.; Vondrová, V.; Bubeníková, T.; Kubovský, I., 2018: Impact of thermal modification on color and chemical changes of spruce and oak wood. Journal of Wood Science, 64 (4): 406-416. https://doi. org/10.1007/s10086-018-1721-0.

21. Tokarski, P.; Nussbaum, R.; 2014: IKEA specification IOS-MAT-0066: Surface coatings and coverings - general requirements. IKEA of Sweden AB.

22. Vardanyan, V.; Galstian, T.; Riedl, B., 2015: Effect of addition of cellulose nanocrystals to wood coatings on color changes and surface roughness due to accelerated weathering. Journal of Coatings Technology and Research, 12 (2): 247-258. https://doi.org/10.1007/s11998-014-9634-3.

23. Wang, X.; Wang, F.; Yu, Z.; Zhang, Y.; Qi, C.; Du, L., 2017: Surface free energy and dynamic wettability of 
... Pavlič, Petrič: Comparison of Visual and Instrumental Assessment of Colour Differences...

wood simultaneously treated with acidic dye and flame retardant. Journal of Wood Science, 63 (3): 271-280. https://doi.org/10.1007/s10086-017-1621-8.

24. ***DIN 6174, 2007: Farbmetrische Bestimmung von Farbmaßzahlen und Farbabständen im angenähert gleichförmigen CIELAB-Farbenraum. Colorimetric evaluation of color coordinates and color differences according to the approximately uniform CIELAB color space (withdrawn)

25. *** CIE, 2001: Technical Report - Improvement to industrial color difference evaluation. CIE Publ. 142. Central Bureau of the CIE, Vienna.

26. ${ }^{* * *} \mathrm{EN} 927-1,2013$ : Paints and varnishes - Coating materials and coating systems for exterior wood. Part 1: Classification and selection.

27. ***EN ISO 11664-4, 2011: Colorimetry. Part 4: CIE 1976 L*a*b* Color space (ISO 11664-4:2008).
28. ***EN ISO 11664-6, 2016: Colorimetry. Part 6: CIEDE2000 Color-difference formula (ISO/CIE 116646:2014).

29. ***EN ISO 2813, 2015: Paints and varnishes - Determination of gloss value at 20 degrees, 60 degrees and 85 degrees (ISO 2813:2014).

\section{Corresponding address:}

Prof. MARKO PETRIČ, PhD

University of Ljubljana

Biotechnical Faculty

Department of Wood Science and Technology

Jamnikarjeva 101, 1000 Ljubljana, SLOVENIA

e-mail: marko.petric@bf.uni-lj.si 